\title{
Distribution of Steller sea lions Eumetopias jubatus in relation to spring-spawning fish in SE Alaska
}

\author{
Jamie N. Womble ${ }^{1,4, *}$, Mary F. Willson ${ }^{1}$, Michael F. Sigler ${ }^{2}$, Brendan P. Kelly ${ }^{1}$, \\ Glenn R. VanBlaricom ${ }^{3}$ \\ ${ }^{1}$ School of Fisheries and Ocean Sciences, University of Alaska Fairbanks, 11120 Glacier Highway, Juneau, Alaska 99801, USA \\ ${ }^{2}$ National Marine Fisheries Service, Alaska Fisheries Science Center, Auke Bay Laboratory, 11305 Glacier Highway, Juneau, \\ Alaska 99801, USA \\ ${ }^{3}$ School of Aquatic and Fishery Sciences, Washington Cooperative Fish and Wildlife Research Unit, \\ University of Washington, Mailstop 355020, Seattle, Washington 98195, USA \\ ${ }^{4}$ Present address: National Marine Fisheries Service, Alaska Fisheries Science Center, Auke Bay Laboratory, \\ 11305 Glacier Highway, Juneau, Alaska 99801, USA
}

\begin{abstract}
Energetic demands are high for Steller sea lions Eumetopias jubatus during spring, when females are pregnant and lactating and males are preparing for extended fasts on breeding territories. Therefore, we predicted that the distribution of sea lions in SE Alaska in spring would be influenced by the distribution of spring spawning aggregations of high-energy prey species (Pacific herring Clupea pallasii and eulachon Thaleichthys pacificus). The spatial distribution of sea lions during spring reflected the distribution of spawning eulachon in northern Southeast Alaska, particularly in Lynn Canal and along the Yakutat forelands. Haulouts with peak numbers of sea lions in spring were located significantly closer to eulachon spawning sites than haulouts that peaked at other times of year. Some haulouts were occupied only during the eulachon spawning period. The maximum number of sea lions at haulouts in spring was inversely correlated with the distance to the closest eulachon aggregation and was positively associated with the number of eulachon within $20 \mathrm{~km}$. Aerial surveys conducted every 7 to $10 \mathrm{~d}$ during March through May in 2002 and 2003 revealed large numbers of sea lions in the water at herring spawning sites in 2002 and 2003; however, there were no significant relationships between the number of herring spawning sites and number of sea lions (except at distances $>60 \mathrm{~km}$ ). The number of sea lions was greater at herring spawning sites in 2003, corresponding to higher herring biomass. Seasonally aggregated, high-energy prey species influence the seasonal distribution of sea lions and may be critical to their reproductive success.
\end{abstract}

KEY WORDS: Steller sea lion · Eumetopias jubatus · Pacific herring · Clupea pallasii · Eulachon · Thaleichthys pacificus $\cdot$ SE Alaska $\cdot$ Forage fishes $\cdot$ Spawning aggregations

\section{INTRODUCTION}

The distribution and abundance of a species is influenced by many abiotic and biotic factors of the environment, including the distribution and abundance of prey. Seasonal changes in prey resources are common, but those at predictable times and locations may be especially important to predators. Seasonally aggregated prey resources can influence timing of breeding cycles, reproductive rates, body size, group size, and distribu- tion of predators (Payne et al. 1986, Hansen 1987, Mehlum et al. 1996, Ben-David 1997, Hilderbrand et al. 1999, Skov et al. 2000, Swartzman \& Hunt 2000, Heyman et al. 2001, Blundell et al. 2002, MacLeod et al. 2004). For most mammalian species, good body condition is critical during the energetically-demanding phases of breeding and lactation (Robbins 1983, Gittleman \& Thompson 1988), and the availability of aggregated high-energy prey may be important in achieving good body condition and ultimately in reproductive success. 
Costs of lactation for females and energetic costs associated with territorial maintenance for males are critical facets of the reproductive biology of pinnipeds. Lactation is the most costly aspect of mammalian reproduction (Gittleman \& Thompson 1988), and differences in the length of the lactation period and offspring dependency among pinniped species are probably related to the amount of energy that each species is able to store prior to parturition (Costa 1993). For Steller sea lion Eumetopias jubatus females, foraging trips continue throughout a protracted lactation period that may range from less than 1 to 3 yr (Pitcher \& Calkins 1981). Energy requirements of dependent pups increase during late lactation, thus increasing the energetic demand upon the female (Oftedal et al. 1987). Steller sea lions depend upon the marine environment for foraging, and they use terrestrial sites for birthing, caring for young, resting, and avoidance of aquatic predators (Bartholomew 1970, Bonner 1984). Thus, they are central-place foragers (Orians \& Pearson 1977) while their pups are land-bound.

Productivity in the marine environment varies seasonally (Laws et al. 1988), and seasonally predictable aggregations of prey may provide an important concentration of food for predators. Pacific salmon Oncorhynchus spp. are energy-rich anadromous fishes that spawn in rivers along the North Pacific rim (Groot \& Margolis 1991), attracting numerous avian and mammalian predators (Willson \& Halupka 1995, Willson et al. 1998, Gende et al. 2001). Also important are other energy-rich fishes, such as Pacific herring Clupea pallasii, capelin Mallotus villosus, Pacific sand lance Ammodytes hexapterus, northern lampfish Stenobrachius leucopsarus, and eulachon Thaleichthys pacificus. All these fish species occur seasonally in the diet of Steller sea lions in Alaska (Pitcher 1981, Merrick et al. 1997, Sinclair \& Zeppelin 2002, Winship \& Trites 2003), but little is known about their life history, spawning patterns, and distribution in Alaska, with the exception of herring (Rounsefell 1930, Rounsefell \& Dalgreen 1935, Carlson 1980). These seasonally abundant, energy-rich forage fish are critical to the biology of many predators (Springer 1992, Byrd et al. 1997, Skov et al. 2000, Bishop \& Green 2001, Litzow et al. 2002, Marston et al. 2002, Rodway et al. 2003). Of the several species of forage fishes, extensive information is available only for Pacific herring and eulachon spawning sites in SE Alaska, and this study focuses on these species.

Although several previous observations have noted pinnipeds aggregating at concentrations of forage fishes in the north Pacific (Bigg 1988, Gende et al. 2001, Marston et al. 2002), no studies have specifically addressed the possible ecological importance of ephemeral concentrations of energy-rich prey fishes as it relates to Steller sea lion life-history. Spring spawning aggregations of forage fishes may be important to Steller sea lion ecology for several reasons. First, energetic demands are high for sea lions during spring when females are pregnant and lactating and males are preparing for extended fasts on their breeding territories (Winship et al. 2002, Winship \& Trites 2003). Second, spring spawning aggregations generally occur at relatively predictable sites and times. Third, herring and eulachon are densely aggregated in spring and are high in lipid content and energy density (Perez 1994, Anthony et al. 2000, Iverson et al. 2002). Therefore, spawning aggregations of eulachon and herring may be of substantial seasonal significance to the nutrition and energy budgets of sea lions when energy demands are at a peak. Under the hypothesis that aggregations of spring-spawning forage fishes are important to the reproductive ecology of Steller sea lions in SE Alaska (SEAK), we predicted that the spatial distribution of sea lions in spring would reflect the distribution of such eulachon and herring aggregations.

The objectives of this study were to provide insight into the seasonal foraging ecology of sea lions by (1) determining the seasonal distribution of sea lions at haulouts in spring, (2) documenting the numbers of sea lions at spring spawning aggregations of herring and eulachon in SE Alaska, and (3) relating the distribution of sea lions to herring and eulachon aggregations. Specifically, we tested the following predictions: (1) Haulouts with peak numbers of sea lions in spring are closer to herring and eulachon aggregations than haulouts with peak numbers at other times of year; (2) the number of sea lions at haulouts in spring is inversely correlated with the distance to the closest herring and eulachon spawning aggregation; (3) the number of sea lions at haulouts in spring is correlated with the number of herring and eulachon spawning aggregations within a limited radius based on foragingtrip distances of sea lions; (4) the number of sea lions observed at spawning aggregations is correlated with the estimated biomass of spawning fishes.

\section{MATERIALS AND METHODS}

Seasonal distribution of Steller sea lions: monthly aerial surveys. Steller sea lions at 25 terrestrial haulouts in northern Southeast Alaska (NSEAK) (Fig. 1) were counted from an airplane monthly from March 2001 through December 2002 to assess their seasonal distribution and use of haulout sites. Surveys were conducted from a floatplane (Cessna 206) with an experienced survey pilot between 10:00 and 16:00 $\mathrm{h}$ (Withrow 1982) and within $3 \mathrm{hr}$ of low tide, weather permitting. The observer-photographer sat in the front right-hand seat and photographed sea lions on shore 


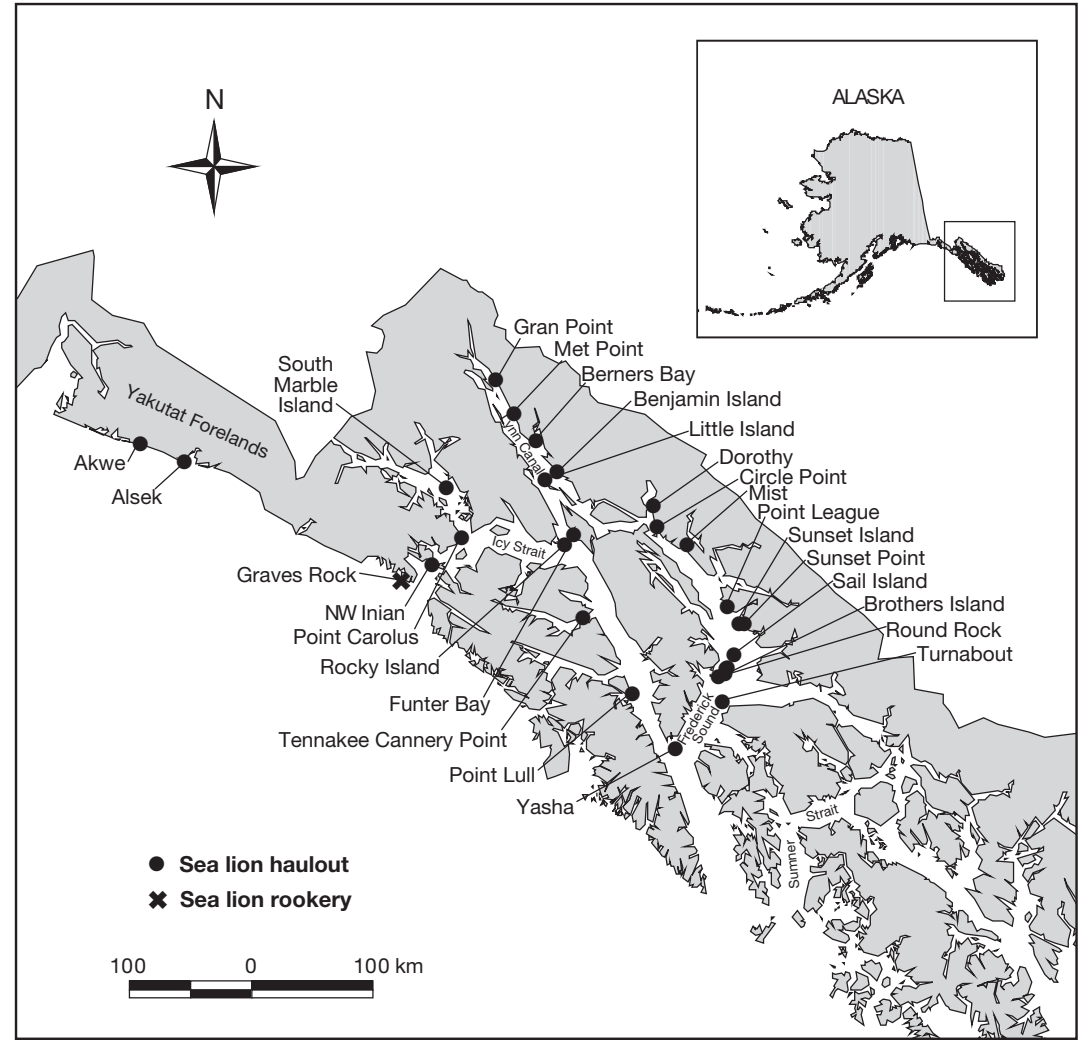

Fig. 1. Eumetopias jubatus. Haulout sites surveyed monthly in SE Alaska and 2 sites on Yakutat forelands surveyed only in spring

through an open window from an altitude of 250 to $300 \mathrm{~m}$ at a speed of 183 to $210 \mathrm{~km} \mathrm{~h}^{-1}$. Along the Yakutat forelands, 2 haulout sites were surveyed, between February and May only, by the US Forest Service (Bill Lucey, Yakutat Ranger District, Yakutat, Alaska, pers. comm.)

Photographic slides of haulouts were taken using a $35 \mathrm{~mm}$ auto-focus camera (Nikon 8008S) equipped with a 70 to $210 \mathrm{~mm}$ zoom lens and an auto-focus digital camera (Nikon D1X) equipped with a 70 to $300 \mathrm{~mm}$ zoom lens. Overlapping photographs were taken if more than 1 photograph was needed to count sea lions at each haulout.

The clearest slide image was projected onto white paper, and each sea lion was marked and counted twice by an experienced counter using a hand-held tally counter. Digital photographic images were stored on digital media cards and later downloaded to a computer. The clearest digital image of each group was imported into geographic information system (GIS) software and each image was counted twice.

Number of Steller sea lions in water at eulachon and herring aggregations. During the spawning season of herring and eulachon (March to May) in 2002 and 2003, we counted sea lions visible on the surface of the water at spring spawning aggregations of Pacific herring and eulachon (Fig. 2). Aerial surveys were conducted as for monthly surveys, but at an altitude of $316 \mathrm{~m}$.

During 2002, Pacific herring and eulachon spawning sites in NSEAK were surveyed 3 to 5 times during the spawning season at approximately 7 to $10 \mathrm{~d}$ intervals; however, sites south of Sumner Strait in southern SE Alaska (SSEAK) were surveyed only once. During 2003, all sites in NSEAK and SSEAK were surveyed 3 to 5 times. We attempted to enumerate all sea lions at herring and eulachon spawning sites; transects were flown parallel to the shoreline approximately $200 \mathrm{~m}$ offshore. When sea lions were detected at the surface of the water, we circled them and took photographs. If sea lions were diving (a dive usually lasts from 60 to $90 \mathrm{~s}$ ), we circled until all sea lions were at the surface. For eulachon spawning sites, we surveyed the entire shoreline of the estuary/bay associated with the river where eulachon spawn. For herring, the entire shoreline associated with herring spawn was surveyed. We assumed fishes were present if we observed (1) commercial and/or subsistence fishing activity, (2) fish schools, (3) spawn/milt on the surface of the water (for herring only), or (4) presence of avian predator aggregations.

Geographical ecology: geographical information system (GIS) database. To synthesize the geographical ecology of Steller sea lions, herring and eulachon, all known current sea lion haulouts in the study area were compiled from observations and a database from the National Marine Fisheries Service. Location and timing of herring and eulachon aggregations were obtained from Alaska Department of Fish \& Game and unpublished sources. These data were incorporated into a database and imported into a GIS software package. A map was created with coverages of Steller sea lion haulouts (Fig. 1), herring spawning locations, and eulachon spawning locations (Fig. 2).

The GIS database was used to determine the distance between Steller sea lion haulout sites and Pacific herring and eulachon spring spawning sites. In particular, we determined (1) swimming distance from sea lion haulouts to the closest eulachon and herring aggregation; (2) number of herring and eulachon spawning aggregations within a swimming distance of 


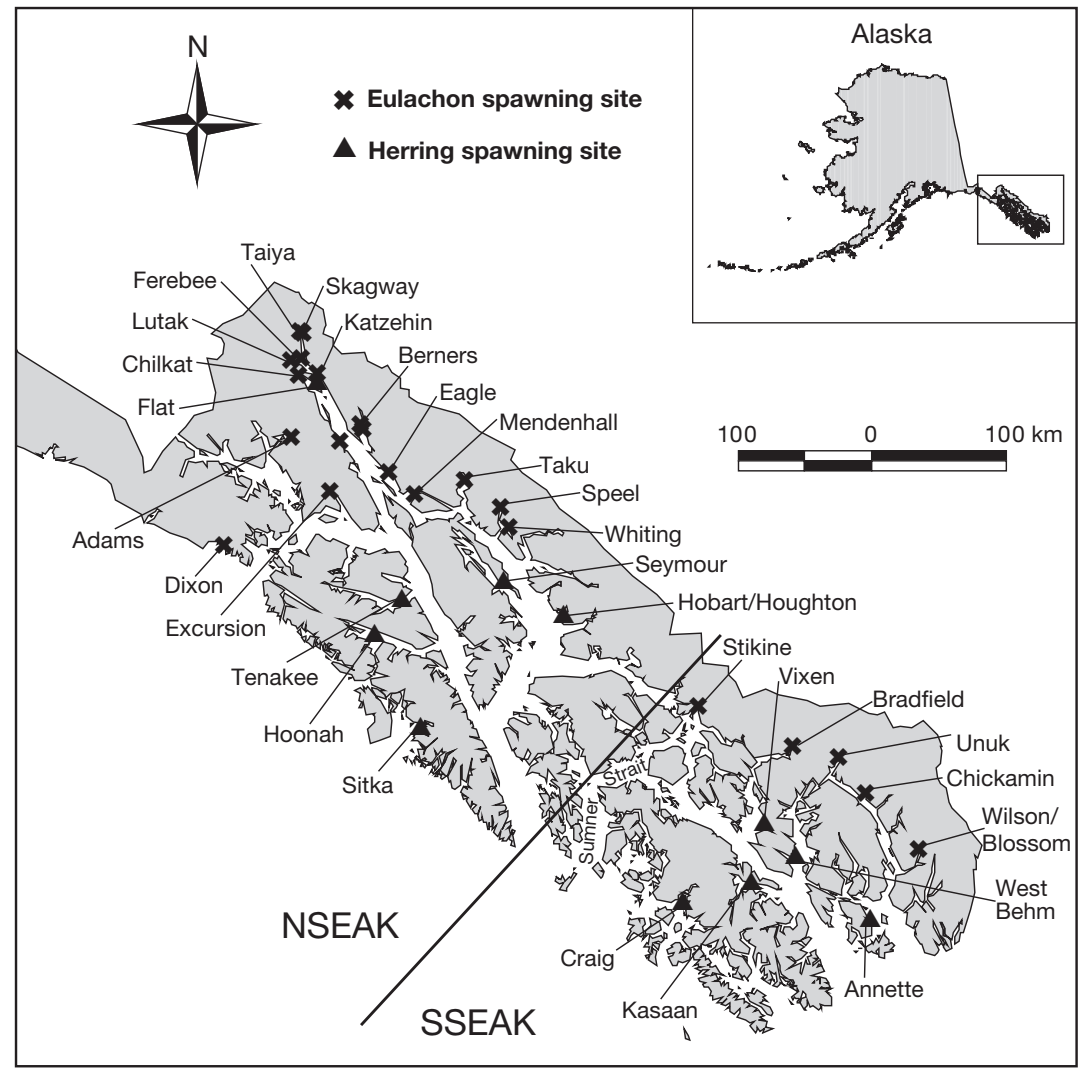

Fig. 2. Clupea pallasii and Thaleichthys pacificus. Spawning sites surveyed during spring 2002 and 2003

20, 40, 60, 80, and $100 \mathrm{~km}$. These distances were based on the range of distances that sea lions may travel on a foraging trip from a haulout (Merrick \& Loughlin 1997, Loughlin et al. 2003, Raum-Suryan et al. 2004).

Seasonal haulout classification. The seasonal use of haulouts was determined by examining the monthly counts of Steller sea lions. We classified haulouts according to seasonal patterns of occupation. Some haulouts peaked in more than 1 season. A peak in number of sea lions was defined as a count that was at least $80 \%$ of the maximum count of sea lions at a haulout for that year. We also tried values of 70 and $90 \%$ of the maximum count of sea lions, and found little difference in the outcome. Seasons were defined as winter (December to February), spring (March to May), summer (June to August), and fall (September to November). The haulouts were classified as Spring Peak Haulouts (peak numbers of sea lions during spring), Spring Ephemeral Haulout (only occupied by sea lions during spring), other haulouts (peak numbers of sea lions in summer, fall or winter).

Fish biomass estimation. Herring biomass was determined from spawn deposition surveys in areas in which commercial herring fisheries were monitored during the spring-spawning season of 2002 and 2003
(K. Hebert, unpubl. data, Alaska Department of Fish and Game). The spawn deposition methods combined SCUBA diver estimates of herring egg deposition, estimates of total area receiving spawn, and average fecundity to derive an estimate of herring spawning biomass (Pritchett \& Hebert 2003).

Biomass data were not available for eulachon spawning sites in SE Alaska, with the exception of Berners Bay (Sigler et al. 2004).

Statistical analyses. For parametric analyses, data were square root-transformed when they did not meet equal variance and normality assumptions of analysis of variance (ANOVA) (Zar 1999). A Spearman rank-order correlation coefficient (Siegel \& Castellan 1988) was used to determine the association between (1) the maximum number of sea lions and the minimum distance to eulachon and herring aggregations and (2) the number of forage fish aggregations within designated distances of sea lion haulouts.

To determine if the sea lion count data were spatially auto-correlated, we examined whether nearby haulouts were more closely related than distant haulouts (e.g. Sullivan 1991). Data on maximum sea lion counts were examined for both 2002 and 2003. For all pair-wise combinations of haulout locations, the squared difference of maximum sea lion count and the inter-pair distance were computed. The squared difference was averaged by a 10 nautical mile (n mile) length interval (the variogram) and plotted versus inter-pair distance. Distance between haulouts was not a significant predictor of the average squared difference between maximum sea lion counts. Therefore, we concluded that the sea lion count data were not spatially correlated at the scale of the $10 \mathrm{n}$ mile length intervals $(2002$, linear regression, $p=0.47, \mathrm{df}=9$; 2003, linear regression, $\mathrm{p}=0.90, \mathrm{df}=9$ ).

\section{RESULTS}

\section{Seasonal distribution of Steller sea lions}

The distribution of sea lions at haulouts varied seasonally. Some sea lion haulouts were only occupied seasonally, whereas other sites were occupied yearround but with peak numbers of sea lions during certain seasons (Table 1, Fig. 3). 
Table 1. Eumetopias jubatus. Maximum (max.), mean, and standard deviation of counts of Steller sea lions at haulouts in NSEAK. nc: no count

\begin{tabular}{|c|c|c|c|c|c|c|}
\hline \multirow{2}{*}{ Location } & \multicolumn{3}{|c|}{2001} & \multicolumn{3}{|c|}{-2002} \\
\hline & Max. & Mean & $\mathrm{SD}$ & Max. & Mean & $\mathrm{SD}$ \\
\hline Alsek $^{a}$ & 770 (Apr) & 326.9 & 272.7 & 1347 (Apr) & 779.0 & 502.0 \\
\hline Dorothy $^{\mathrm{a}}$ & 15 (May) & 1.5 & 4.7 & 283 (Apr) & 27.71 & 20.39 \\
\hline Berners Bay ${ }^{\mathrm{a}}$ & 13 (Apr) & 1.08 & 1.08 & 0 & 0 & 0 \\
\hline Gran Point & 850 (May) & 323.2 & 351.2 & 1087 (Apr) & 390.42 & 404.9 \\
\hline Mist & 371 (May) & 71.33 & 118.3 & 319 (Apr) & 75.78 & 100.1 \\
\hline Met Point & 129 (May) & 30.3 & 46.1 & 221 (Nov) & 59.62 & 74.5 \\
\hline South Marble Island & 746 (Apr) & 422.77 & 199.9 & 791 (Oct) & 468.83 & 201.4 \\
\hline Sunset Island & 706 (Jul) & 246.88 & 264.5 & 740 (May) & 271.06 & 233.8 \\
\hline Graves Rocks & 1114 (Aug) & 551.88 & 359.9 & $1218(\mathrm{Jul})$ & 513.75 & 354.3 \\
\hline Benjamin Island & 797 (Oct) & 248.66 & 243.2 & 747 (Dec) & 268.16 & 252.8 \\
\hline Round Rock & 42 (Oct) & 14.4 & 16.2 & 63 (Oct) & 32.38 & 21.8 \\
\hline Point Lull & 266 (Apr) & 78.22 & 90.9 & 218 (Mar) & 101.4 & 92.0 \\
\hline Sunset Point & nc & nc & $\mathrm{nc}$ & 229 (Apr) & 53.64 & 81.8 \\
\hline Southwest Brothers & 1283 (Aug) & 483.25 & 355.3 & 1752 (Aug) & 544.07 & 424.1 \\
\hline Yasha Island & 769 (Aug) & 283 & 204.6 & 1664 (Jul) & 324.21 & 445.6 \\
\hline Sail Island & 644 (Aug) & 279.25 & 249.0 & 1124 (Sep) & 281.07 & 385.9 \\
\hline Tenakee Cannery Point & 182 (Oct) & 34.6 & 60.8 & 251 (Dec) & 55.21 & 82.2 \\
\hline Circle Point & 286 (Oct) & 76.88 & 104.8 & 240 (Oct) & 60.68 & 84.0 \\
\hline Turnabout Island & 181 (Oct) & 27.75 & 62.7 & 187 (Oct) & 27.75 & 62.6 \\
\hline West Brothers & 421 (Oct) & 74 & 151.2 & 291 (Dec) & 66 & 109.9 \\
\hline NW Inian Island & 291 (Oct) & 126.77 & 81.7 & 345 (Jul) & 129.5 & 90.4 \\
\hline Rocky Island & 255 (Oct) & 93.5 & 96.1 & 385 (Oct) & 121.46 & 110.6 \\
\hline Point Carolus & 114 (Oct) & 19.8 & 38.7 & 278 (Oct) & 30.15 & 77.1 \\
\hline Point League & 50 (Mar) & 6.55 & 16.4 & 364 (Dec) & 59.07 & 109.8 \\
\hline Little Island & 376 (Sep) & 116.3 & 178.2 & 685 (Sep) & 62.6 & 182.6 \\
\hline Funter Bay & 44 (Feb) & 11.38 & 5.06 & 40 (Jan) & 10 & 18.3 \\
\hline
\end{tabular}

Prediction 2: number of sea lions versus distance to closest forage fish aggregation. The maximum number of sea lions at haulouts in spring was inversely correlated with the distance to the closest forage fish aggregation (herring and eulachon combined) only in 2002 (2002: $\mathrm{r}_{\mathrm{s}}=-0.43, \mathrm{n}=25, \mathrm{p}<0.025$; 2003: $\mathrm{r}_{\mathrm{s}}=-0.18, \mathrm{n}=25,0.10<\mathrm{p}<$ 0.25 (Fig. 5). Although, there was no significant association in 2003, there was a similar trend to that in 2002. The maximum number of sea lions at haulouts in spring was correlated between 2002 and $2003\left(\mathrm{r}^{2}=\right.$ $\left.0.60, F_{1,23}=35.13, \mathrm{n}=25, \mathrm{p}<0.05\right)$.

When analyzed separately the correlation of sea lions with distance to eulachon aggregations was marginally significant in 2002 but not in 2003 (2002: $\mathrm{r}_{\mathrm{s}}=-0.31$, $\mathrm{n}=25,0.05<\mathrm{p}<0.10 ; 2003: \mathrm{r}_{\mathrm{s}}=$ $-0.18, \mathrm{n}=25,0.10<\mathrm{p}<0.25)$. There was no significant correlation between the maximum number of sea lions at haulouts in spring and distance to herring aggregations (2002: $\mathrm{r}_{\mathrm{s}}=-0.06, \mathrm{n}=25, \mathrm{p}>0.25$; $2003 \mathrm{r}_{\mathrm{s}}=0.16, \mathrm{n}=25,0.10<\mathrm{p}<$ $0.25)$.

\section{Spatial relationships between sea lion haulouts and forage fish aggregations}

Prediction 1: haulout type versus distance to closest eulachon and herring aggregation. Spring peak haulouts were located significantly closer to eulachon spawning sites than haulouts that peaked at other times of year (ANOVA, 2001: $F_{1,22}=5.92, \mathrm{p}=0.024$; 2002: $F_{1,23}=8.13, \mathrm{p}=0.009$ ). Spring peak haulouts were located on average $28.0 \pm 9.01 \mathrm{~km}$ from the closest eulachon spawning site (Fig. 4). Spring ephemeral haulouts at Berners Bay, Alsek, Akwe, and Dorothy were occupied only in spring near eulachon runs. Haulouts that peaked at other times of year were located on average $70.63 \pm 6.95 \mathrm{~km}$ from the closest eulachon spawning site (Fig. 4). However, the distance to herring spawning sites was not significantly different between spring peak and other peak haulouts (ANOVA, 2001: $F_{1,22}=1.25 ; \mathrm{p}=0.28 ; 2002: F_{1,22}=0.73$, $\mathrm{p}=0.401$ ). Spring peak haulouts were located on average $37.4 \pm 7.6 \mathrm{~km}$ from the closest herring spawning site whereas haulouts that peaked at other times of year were located $26.33 \pm 3.64 \mathrm{~km}$ from the closest herring spawning site (Fig. 4).
Prediction 3: number of sea lions versus number of eulachon and herring aggregations. The maximum number of sea lions at haulouts in spring was positively associated with the number of eulachon and herring (combined) spawning sites within $20 \mathrm{~km}$ in 2002 and $2003\left(2002: \mathrm{r}_{\mathrm{s}}=0.56, \mathrm{n}=24, \mathrm{p}<0.0025 ; 2003: \mathrm{r}_{\mathrm{s}}=0.42\right.$, $\mathrm{n}=24, \mathrm{p}<0.025$ ) (Table 2). However, this relationship reflects only an association with eulachon spawning sites, because there was little association with the number of herring spawning sites except at distances greater than $60 \mathrm{~km}$ (Table 2).

\section{Steller sea lions in water at spring-spawning fish aggregations}

The sea lions in the water during spring at the spawning aggregations of herring and eulachon were counted. The numerical response of sea lions to eulachon spawning sites was much greater in NSEAK than in SSEAK. Eulachon spawning sites in NSEAK at Berners Bay, Lutak Inlet, and Taku Inlet attracted over 200 sea lions during the spawning season in 2002. The number of sea lions peaked at Taku Inlet (235 sea 


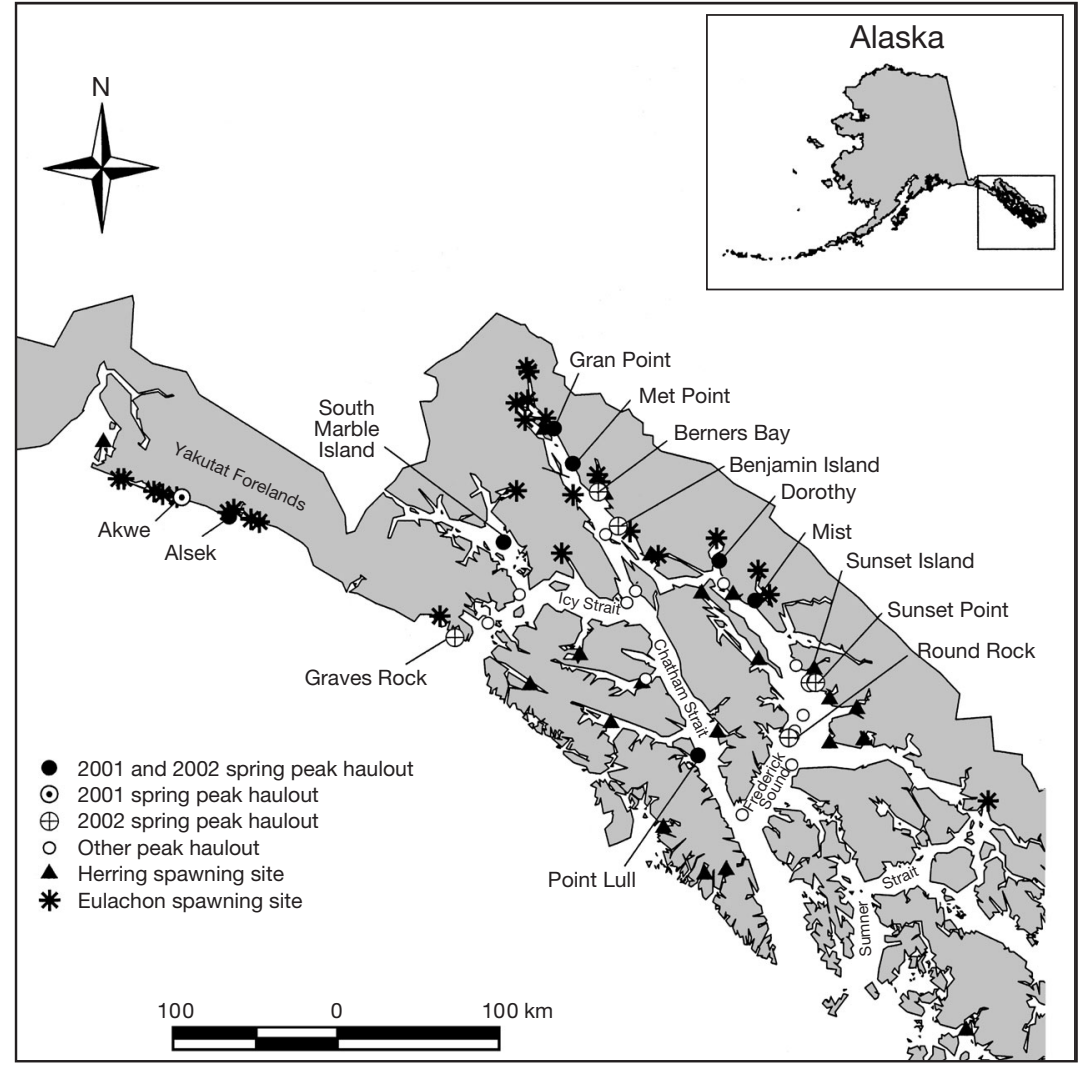

Fig. 3. Eumetopias jubatus. Haulouts where numbers of sea lions ashore peaked in 2001 and 2002 in relation to spawning locations of eulachon and herring in SE Alaska

lions) on April 10, at Berners Bay (949 sea lions) on April 18, and at Lutak Inlet (506 sea lions) on April 29, 2002. The maximum number of sea lions observed at Berners Bay, Lutak Inlet, and Taku Inlet was greater in 2002 than in 2003. During 2003, only Berners Bay and Taiya Inlet attracted over 200 sea lions. In SSEAK, the only sea lion aggregation detected at an eulachon spawning site was a group of 25 sea lions observed at Bradfield Canal (Fig. 6).

Sea lions attended herring spawning sites in NSEAK and SSEAK. At most herring spawning sites, the maximum number of sea lions observed was greater in 2003 than in 2002, corresponding to higher herring biomass at 4 of the spawning sites (Fig. 7). Herring spawning sites at Craig, Sitka, and Seymour attracted more than 200 sea lions in both years. Tenakee, Hoonah Sound, and Hobart herring spawning sites had 50 to 199 sea lions present (Fig. 7A).

Prediction 4: number of sea lions versus herring biomass. Although sea lions were recorded in the water at herring spawning sites in NSEAK and SSEAK, the correlation between the maximum number of sea lions (square-root) and the (log) biomass of herring was only marginally significant $\left(\mathrm{r}^{2}=0.23, \mathrm{n}=14, \mathrm{p}=0.08\right)$ (Fig. 8).

\section{DISCUSSION}

\section{Sea lion distribution in relation to eulachon spawning sites}

The spatial distribution of sea lions during spring clearly reflects the distribution of spawning eulachon in NSEAK, particularly in Lynn Canal and along the Yakutat forelands. Sea lions were concentrated near spawning runs and in areas with a high density of spawning runs. In some cases, haulouts (i.e. Alsek, Dorothy, Berners Bay and Akwe) were occupied only during the time of a nearby eulachon spawning run. Similarly in British Columbia at Sands Head near the mouth of the Fraser River, sea lions were observed only in spring between late March and late May from 1978 to 1982, which coincided with eulachon entering the Fraser River to spawn (Bigg 1988).

The concentration of sea lions in these areas reduced the travel distance to the spawning runs and thus decreased foraging costs for sea lions. Use of haulouts close to rich prey resources allows females with dependent pups to conserve travel energy and allocate more resources to pups (Boyd 1998). In addition, using haulout sites close to rich prey resources may allow dependent young to accompany their mothers to sea,

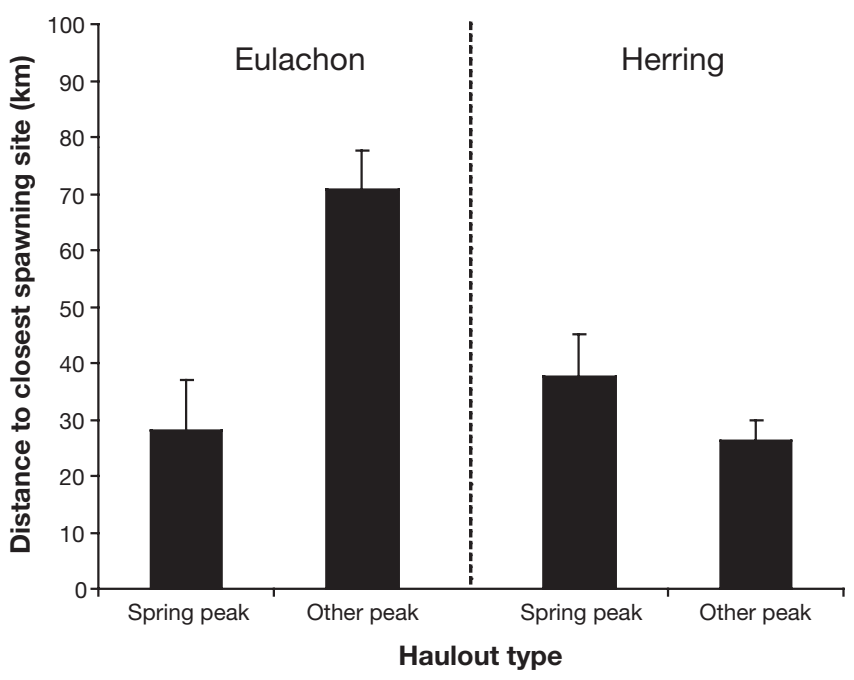

Fig. 4. Eumetopias jubatus. Mean distance to closest eulachon spawning and herring spawning site from spring peak and other haulouts 


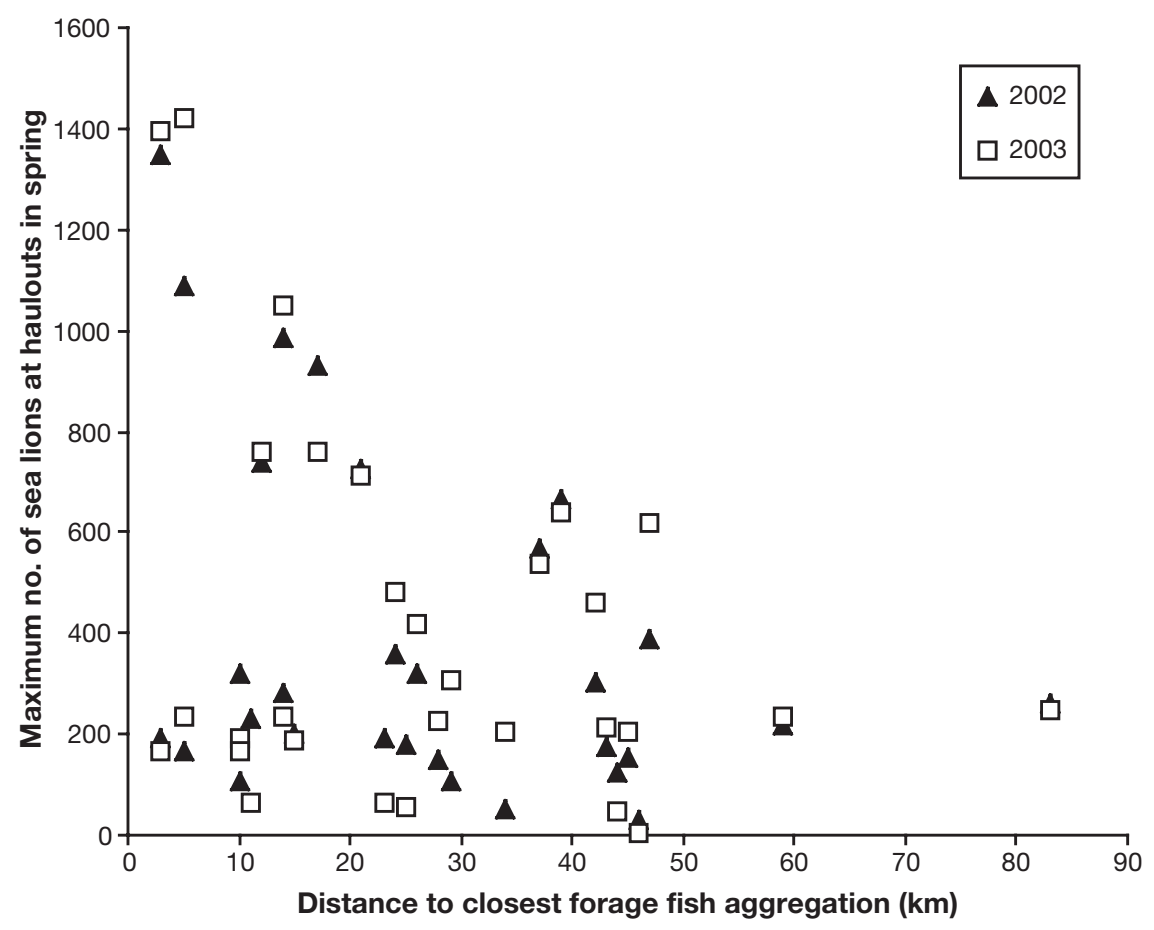

Fig. 5. Eumetopias jubatus. Scatterplot of maximum number of sea lions at haulouts in spring in relation to closest forage fish aggregation
In Lynn Canal on April 18, 2002, approximately $4 \%$ (949 sea lions) of the estimated sea lion population of SE Alaska was observed in Berners Bay at a eulachon spawning aggregation. On the same day there were an additional 1244 sea lions at the 3 haulout sites in Lynn Canal within $60 \mathrm{~km}$ of Berners Bay. It is probable that sea lions using these haulout sites during this time period are also visiting the eulachon spawning aggregation at Berners Bay and so may account for as much as $10 \%$ of the estimated sea lion population in SE Alaska (Sigler et al. 2004). On April 21, 2003, 5.5\% of the estimated sea lion population of SE Alaska was found at Berners Bay and at haulouts within $60 \mathrm{~km}$ (Sigler et al. 2004). The total number of sea lions attending the runs may be considerably larger. It is likely that there is turnover in the number of sea lions visiting the eulachon spawning sites, as they may return to haulouts to provision their pups.

as the average distance traveled by sea lion pups less than 9 mo olds was $\leq 15 \mathrm{~km}$ in SE Alaska (RaumSuryan et al. 2004).

Use of haulouts closest to spawning runs also permits better tracking of the arrival and departure of the temporary and localized prey. The pulsed nature of eulachon runs makes the spawning period difficult to detect, and sea lions move to haulouts and raft in areas close to eulachon spawning sites.

However, as evident from Fig. 5, some haulouts were not located close to spawning runs, thus suggesting that some sea lions are not responding to the runs. They may be exploiting other unassessed prey resources. It is also possible that non-breeding individuals are less likely to capitalize on spawning runs than breeding individuals.
Although sea lions were numerous at eulachon spawning sites in NSEAK, few were detected at eulachon spawning sites in SSEAK. There are several possible explanations for this. Eulachon runs in SSEAK may not be as large as those in NSEAK; however, there are currently no data available for eulachon biomass in SE Alaska, with the exception of Berners Bay (Sigler et al. 2004). In addition, some bays in NSEAK have more than one river used by spawning eulachon, and thus potentially a greater concentration of eulachon for predators to exploit. In some areas such as Berners Bay, additional forage fish species including Pacific herring and capelin spawn in the bay during spring. Finally, in some areas in British Columbia near the southern border of SSEAK, the size of eulachon spawning runs has decreased and industrial trawl fish-

Table 2. Eumetopias jubatus. Spearman rank correlation coefficients between number of forage fish aggregations (eulachon and herring) at designated distances and the maximum number of sea lions at haulouts in spring of 2002 and 2003. All FFa: all forage fish aggregations, i.e. eulachon and herring combined

\begin{tabular}{|c|c|c|c|c|c|c|c|c|c|c|c|c|}
\hline \multirow{3}{*}{$\begin{array}{l}\text { Distance } \\
(\mathrm{km})\end{array}$} & \multicolumn{4}{|c|}{ - Eulachon } & \multicolumn{4}{|c|}{ - Herring -} & \multirow{2}{*}{\multicolumn{4}{|c|}{ All FFa }} \\
\hline & \multicolumn{2}{|c|}{2002} & \multicolumn{2}{|c|}{2003} & \multicolumn{2}{|c|}{2002} & \multicolumn{2}{|c|}{2003} & 2002 & & & 2003 \\
\hline & $\mathrm{r}$ & $\mathrm{p}$ & $\mathrm{r}$ & $\mathrm{p}$ & $\mathrm{r}$ & $\mathrm{p}$ & r & $\mathrm{p}$ & $\mathrm{r}$ & $\mathrm{p}$ & r & $\mathrm{p}$ \\
\hline $0-20$ & 0.44 & $<0.025$ & 0.26 & $<0.25$ & 0.32 & $<0.10$ & 0.26 & $<0.25$ & 0.56 & $<0.0025$ & 0.42 & $<0.025$ \\
\hline $0-40$ & 0.31 & $<0.10$ & 0.17 & $<0.25$ & 0.01 & $>0.25$ & -0.11 & $>0.25$ & 0.33 & $<0.10$ & 0.14 & $<0.25$ \\
\hline $0-60$ & 0.08 & $>0.25$ & -0.23 & $<0.25$ & -0.32 & $<0.10$ & -0.23 & $<0.25$ & 0 & $>0.25$ & -0.01 & $>0.25$ \\
\hline $0-80$ & 0.05 & $>0.25$ & 0.01 & $>0.25$ & -0.36 & $>0.05$ & -0.46 & $<0.025$ & -0.09 & $>0.25$ & -0.15 & $<0.25$ \\
\hline $0-100$ & -0.06 & $>0.25$ & -0.09 & $>0.25$ & -0.38 & $>0.05$ & -0.39 & $<0.05$ & -0.18 & $<0.25$ & -0.24 & $<0.25$ \\
\hline
\end{tabular}




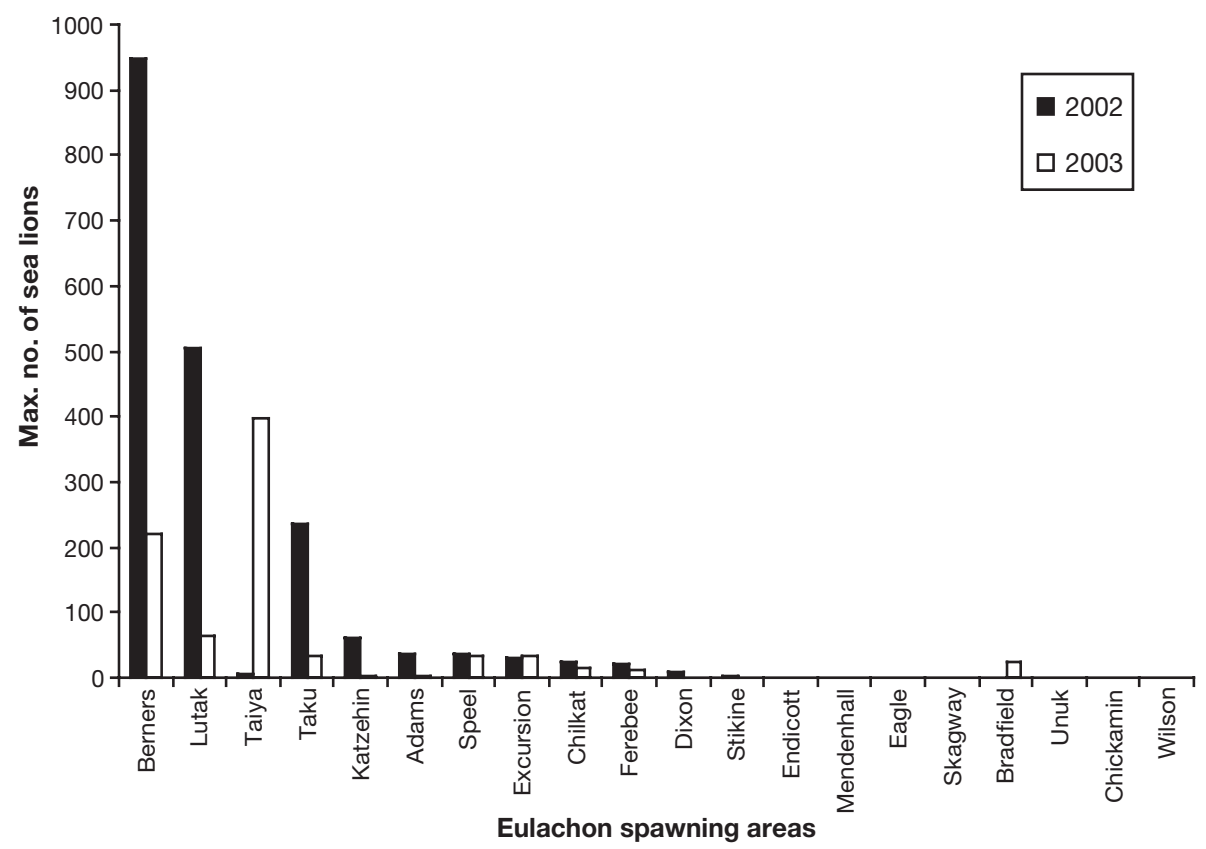

Fig. 6. Eumetopias jubatus. Maximum numbers in the water at eulachon spawning sites in SE Alaska in 2002 and 2003 of occurrence; $\mathrm{n}=678$ scat samples) (Womble \& Sigler unpubl. data). The importance of herring in the diet of sea lions throughout the fall and winter in some areas may explain the lack of observed associations between sea lion numbers and herring spawning sites. If sea lions are exploiting herring throughout the winter, it may not be advantageous to change haulout locations during the spring spawning season, since herring form high-density aggregations during fall for up to 6 mo of the year (Thomas \& Thorne 2001). Although the energy density and fat content of herring decreases in spring prior to the spawning season (Paul et al. 1998), herring are still higher in energy content than other species such as pollock (Iverson et al. 2002). eries have been developed (Hay et al. 1996) that have the potential to diminish the biomass of fish available to predators.

\section{Sea lion distribution in relation to herring spawning sites}

In contrast to the observed responses to eulachon runs, sea lions were not observed to congregate at haulouts near herring spawning aggregations. However, large numbers of sea lions were observed in the water at herring spawning sites in 2002 and 2003, although there were no significant relationships between the number of herring spawning sites and numbers of sea lions except at distances $>60 \mathrm{~km}$, which is probably not biologically meaningful. These concentrations of sea lions were associated (marginally significant) with estimates of herring biomass. Furthermore, annual differences in the number of sea lions observed corresponded to annual differences in herring biomass, particularly in some locations (Sitka Sound, Craig, Hoonah Sound and Hobart).

Herring appear to be an important prey resource for sea lions in spring, as evidenced by the number of sea lions counted in the water at herring spawning sites, but they are important in fall and winter in some areas (Thomas \& Thorne 2001). Herring was the most frequent prey item in sea lion scat during winter at Benjamin Island in SE Alaska, from 2001 to 2003 (88.9\% frequency

\section{Other seasonal prey resources}

Other seasonal prey species, such as Pacific salmon, provide high-energy resources at other times of year and may influence the distribution of sea lions. For example, the total number of sea lions in Frederick Sound increased during July, August, and September (J. Womble unpubl. data) and coincided with the return of pink salmon Oncorhynchus gorbuscha to the area. Frederick Sound is one of the main migratory corridors for pink salmon returning to SEAK spawning grounds in July and August (Heard 1991). Energy densities of salmon are higher after oceanic feeding than after entry into fresh water (Hendry \& Berg 1999), thereby providing seasonally available high-energy prey to sea lions.

\section{Detecting seasonal pulses in sea lion distribution and diet}

Although seasonal changes in the distribution and abundance of sea lions have been documented (Bonnot 1951, Bartholomew \& Boolootian 1960, Kenyon \& Rice 1961, Mathisen \& Lopp 1963, Smith 1972, Mate 1975, Harestad 1977, Sullivan 1980, Calkins \& Pitcher 1982, Bigg 1988, Sease \& York 2003), previous efforts have focused predominantly on the breeding season. Documenting the abundance of Steller sea lions in the breeding season is important; however, elucidating seasonal shifts in abundance and distribution is also im- 


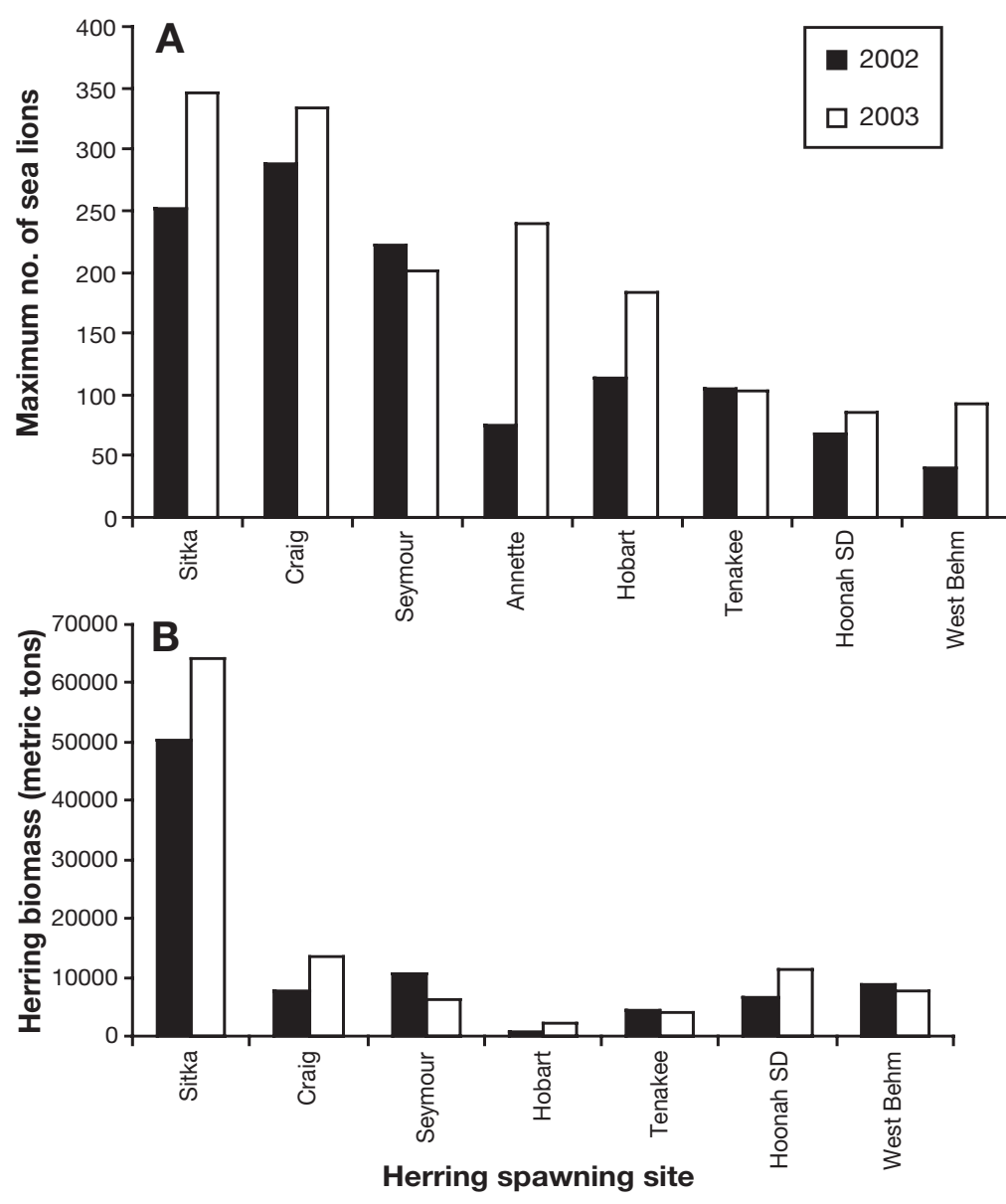

Fig. 7. Eumetopias jubatus and Clupea pallasii. (A) Maximum numbers of sea lions in the water and (B) estimated herring biomass at herring spawning sites in SE Alaska in 2002 and 2003. Herring biomass data provided by Alaska Department of Fish and Game, Division of Commercial

Fisheries, Alaska monly detected prey species in sea lion scat during the breeding season (Merrick et al. 1997, Sinclair \& Zeppelin 2002), and dietary studies during the breeding season would not reflect the seasonal importance of eulachon. At Benjamin Island, eulachon were found in only $8.6 \%$ of scat samples collected quarterly from 2001 to 2003; however, their frequency was greatest in April (19.0\% frequency of occurrence; $\mathrm{n}=152$ scat samples) and corresponded to the spring-spawning season of eulachon (J. Womble \& M. Sigler unpubl. data). Furthermore, when Steller sea lions aggregate at the eulachon and herring spawning sites in spring, they do not return to haulout sites regularly but often raft up, rest, and defecate in the water near the spawning site, so even weekly scat collection at haulouts during the spring may not reflect the importance of this seasonally pulsed prey in the diet. In addition, prey species with small otoliths, such as eulachon and capelin, may be underestimated in the diet when consumed together with large species such as pollock (Tolitt et al. 2003). Thus, scat collections should be used in combination with other methods such as fatty acid (Iverson et al. 1997) and stable isotope analysis (Kurle 2002) and should be conducted frequently enough to determine the presence of seasonally pulsed prey, such as eulachon. portant as it relates to life-history characteristics of sea lions and their prey species. The availability, concentration, and energy density of prey species changes seasonally, so some fish species may be more valuable to exploit than others at particular times of year (Jangaard 1974, Montevecchi \& Piatt 1984, Mårtensson et al. 1996, Iverson et al. 2002). Furthermore, data on seasonal shifts in sea lion abundance are important in furthering our understanding and interpretation of annual trends in the abundance of sea lions (Bigg 1988).

Traditional methods of determining the presence of prey species in pinniped diets, such as scat analysis, may not be sufficient to detect pulsed prey resources. Eulachon probably comprise an important prey species for sea lions in spring but they are not a com-

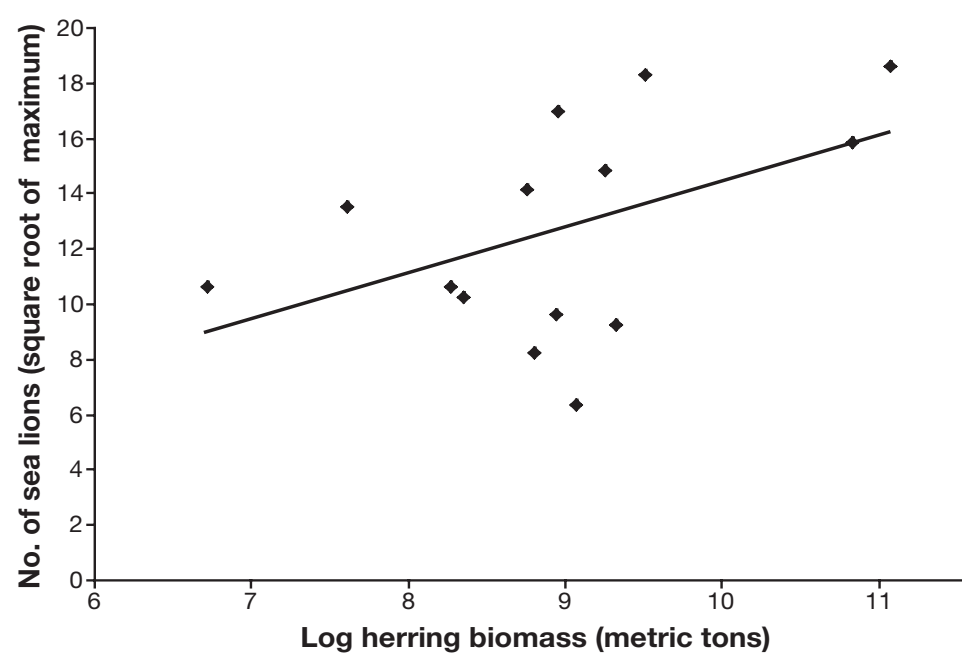

Fig. 8. Clupea pallasii. Scatterplot of (log) herring biomass in relation to (square-root) maximum number of sea lions Eumetopias jubatus at herring spawning sites in SE Alaska for 2002 and 2003 


\section{Implications of spring-spawning fish aggregations for Steller sea lions}

To meet the energetic demands of the costly otariid reproductive strategy, using haulouts that are close to high-density, high-energy prey resources is advantageous during spring, an energetically demanding time for sea lions. Foraging at spring spawning fish aggregations should allow Steller sea lion males to arrive at rookeries in good body condition. Larger, more fit males are likely to successfully defend territories for longer periods of time (Boyd \& Duck 1991) and mate with more females, thus increasing their reproductive success (Bartholomew 1970). Females nursing a dependent pup may need to consume twice the energy that a female without a pup would require (Winship et al. 2002) and may be pregnant and simultaneously nursing a pup during spring. Good body condition for females prior to the breeding season is critical for sea lions to give birth to healthy pups and to have the ability to nourish their young for an extended lactation period. Pitcher et al. (1998) found that the probability of a female sea lion being pregnant during late gestation was positively related to body condition, including mass and blubber index. Thus access to high-energy prey resources during late gestation may be critical for successful reproduction in female sea lions. Ultimately, seasonally aggregated, high-energy prey species, particularly eulachon, influence the seasonal distribution of sea lions in some areas of SEAK. To further our understanding of the importance of seasonally pulsed resources to sea lion life history, it will be necessary to examine body condition, foraging costs, and fitness directly.

Acknowledgements. We thank J. Norvell of Tal Air, a skilled pilot and keen observer, for many safe hours in the air. $M$. Masden also provided aerial survey expertise in Ketchikan. J. Scott-Ashe, K. Blejwas, M. Kunnasranta, K. White, B. Williams and numerous volunteers have persevered in all seasons during aerial surveys. W. Lucey (USFS) conducted aerial surveys along the Yakutat forelands. K. Hebert (ADF\&G) provided herring data for SEAK. L. J. Haldorson, T. C. Shirley, and 3 anonymous reviewers provided helpful reviews of earlier drafts of the manuscript. Funding for this study was provided by the Rasmuson Fisheries Research Fellowship Center at the University of Alaska Fairbanks to J.N.W., University of Alaska, National Marine Fisheries Service-Steller Sea Lion Research Initiative Award \# NA16FX1419, and the National Marine Fisheries Service-Auke Bay Laboratory. Monthly aerial surveys were carried out under Marine Mammal Protection Act permit no. 782-153202.

\section{LITERATURE CITED}

Anthony JA, Roby DD, Turco TR (2000) Lipid content and energy density of forage fishes from the northern Gulf of Alaska. J Exp Mar Biol Ecol 248:53-78
Bartholomew GA (1970) A model for the evolution of pinniped polygyny. Evolution 24:546-559

Bartholomew GA, Boolootian RA (1960) Numbers and population structure of the pinnipeds on the California Channel Islands. J Mammal 41:366-375

Ben-David M (1997) Timing of reproduction in wild mink: the influence of spawning Pacific salmon. Can J Zool 75: 376-383

Bigg MA (1988) Status of the Steller sea lion, Eumetopias jubatus, in Canada. Can Field-Nat 102:315-336

Bishop MA, Green SP (2001) Predation on Pacific herring Clupea pallasii spawn by birds in Prince William Sound, Alaska. Fish Oceanogr 10 (Suppl 1):149-158

Blundell GM, Ben-David M, Bowyer RT (2002) Sociality in river otters: cooperative foraging strategies or reproductive strategies? Behav Ecol 13:134-141

Bonner WN (1984) Lactation strategies in pinniped: problems for a marine mammalian group. Symp Zool Soc 51: 253-272

Bonnot P (1951) The sea lions, seals, and sea otter of the California coast. Calif Fish Game 37:371-389

Boyd IL (1998) Time and energy constraints in pinniped lactation. Am Nat 152:717-728

Boyd IL, Duck CD (1991) Mass changes and metabolism in territorial male Antarctic fur seals Arctocephalus gazella. Physiol Zool 64:375-392

Byrd GV, Merrick RL, Piatt JF, Norcross BL (1997) Seabird, marine mammal, and oceanography coordinated investigations (SMMOCI) near Unimak Pass, Alaska. In: Forage fishes in marine ecosystems. Proceedings of an International Symposium on the Role of Forage Fishes in Marine Ecosystems. Alaska Sea Grant College Program Report No. 97-01, University of Alaska, Fairbanks, p 351-364

Calkins DG, Pitcher KW (1982) Population assessment, ecology and trophic relationships of Steller sea lions in the Gulf of Alaska. In: Environmental Assessment of the Alaska Continental shelf. Final reports of Principal Investigators. U.S. Department of the Commerce and U.S. Department of Interior, OCSEAP, Anchorage, AK, Volume $19, \mathrm{p} 445-546$

Carlson HR (1980) Seasonal distribution and environment of Pacific herring near Auke Bay, Lynn Canal, Southeastern Alaska. Trans Am Fish Soc 109:71-78

Costa DP (1993) The relationship between reproductive and foraging energetics and the evolution of Pinnipedia. Symp Zool Soc 66:293-314

Gende SM, Womble JN, Willson MF, Marston BH (2001) Cooperative foraging in Steller sea lions (Eumetopias jubatus). Can Field-Nat 115:355-356

Gittleman JL, Thompson SD (1988) Energy allocation in mammalian reproduction. Am Zool 28:863-875

Groot C, Margolis L (eds) (1991) Pacific salmon life histories. University of British Columbia Press, Vancouver

Hansen AJ (1987) Regulation of bald eagle reproductive rates in southeast Alaska. Ecology 6:1387-1392

Harestad AS (1977) Seasonal abundance of northern sea lions, Eumetopias jubatus (Schreber), at McInnes Island, British Columbia. Syesis 10:173-174

Hay DE, Boutillier J, Joyce M, Langford G (1996) The eulachon (Thaleichthys pacificus) as an indicator species in the North Pacific. In: Forage fishes in marine ecosystems. Proceedings of an International Symposium on the Role of Forage Fishes in Marine Ecosystems. Alaska Sea Grant College Program Report No. 97-01, University of Alaska, AK, p 509-530

Heard WR (1991) Life history of pink salmon Oncorhynchus gorbuscha. In: Groot C, Margolis L (eds) Pacific salmon 
life histories. University of British Columbia Press, Vancouver, p 119-230

Hendry AP, Berg OK (1999) Secondary sexual characteristics, energy use, senescence, and the cost of reproduction in sockeye salmon. Can J Zool 77:1663-1675

Heyman WD, Graham RT, Kjeríve B, Johannes RE (2001) Whale sharks Rhincodon typus aggregate to feed on fish spawn in Belize. Mar Ecol Prog Ser 215:275-282

Hilderbrand GV, Schwartz CC, Robbins CT, Jacoby ME, Hanley TA, Arthur SM, Servheen C (1999) The importance of meat, particularly salmon, to body size, population productivity, and conservation of North American brown bears. Can J Zool 77:132-138

Iverson SJ, Frost KJ, Lang SLC (2002) Fat content and fatty acid composition of forage fish and invertebrates in Prince William Sound, Alaska: factors contributing to among and within species variability. Mar Ecol Prog Ser 241:161-181

Jangaard PM (1974) The capelin Mallotus villosus: biology, distribution, exploitation, utilization and composition. Bull Fish Res Board Can 186:1-70

Kenyon KW, Rice DW (1961) Abundance and distribution of the Steller sea lion. J Mammal 42:223-234

Kurle CM (2002) Stable-isotope ratios of blood components from captive northern fur seals Callorhinus ursinus and their diet: applications for studying the foraging ecology of wild otariids. Can J Zool 80:902-909

Laws EA, Bienfang PK, Ziemann DA, Conquest LD (1988) Phytoplankton population dynamics and the fate of production during the spring bloom in Auke Bay, Alaska. Limnol Oceanogr 33:57-65

Litzow MA, Piatt JF, Prichard AK, Roby DD (2002) Response of pigeon guillemots to variable abundance of high-lipid and low-lipid prey. Oecologia 132:286-295

Loughlin TR, Sterling JT, Merrick RL, Sease JL, York AE (2003) Diving behavior of immature Steller seal ions (Eumetopias jubatus). Fish Bull US Natl Mar Fish Serv 101:566-582

MacLeod K, Fairbairns R, Gill A, Fairbairns B, Gordon J, Blair-Myers C, Parsons ECM (2004) Seasonal distribution of minke whales Balaenoptera acutorostrata in relation to physiography and prey off the Isle of Mull, Scotland. Mar Ecol Prog Ser 277:263-274

Marston BH, Willson MF, Gende SM (2002) Predator aggregations during eulachon Thaleichthys pacificus spawning runs. Mar Ecol Prog Ser 231:229-236

Mårtensson PE, Gotaas ARL, Nordøy ES, Blix AS (1996) Seasonal changes in energy density of prey of northeast Atlantic seals and whales. Mar Mammal Sci 12:635-640

Mate BR (1975) Annual migration of the Steller sea lion and California sea lion along the coast of Oregon. Rapp P-V Réun Cons Perm Int Explor Mer 169:455-461

Mathisen OA, Lopp RJ (1963) Photographic census of the Steller sea lion herds in Alaska, 1956-1958. US Fish Wildl Serv Spec Sci Rep Wildl 424

Mehlum F, Hunt GL, Klusek Z, Decker MB, Nordlund N (1996) The importance of prey aggregations to the distribution of Brünnich's guillemots in Storfjordern, Svalbard. Polar Biol 16:537-547

Merrick RL, Loughlin TR (1997) Foraging behavior of adult female and young-of-the-year Steller sea lions in Alaskan waters. Can J Zool 75:776-786

Merrick RL, Chumbley MK, Byrd GV (1997) Diet diversity of Steller sea lions Eumetopias jubatus and their population decline in Alaska: a potential relationship. Can J Fish Aquat Sci 54:1342-1348

Montevecchi WA, Piatt JF (1984) Composition and energy contents of mature inshore spawning capelin Mallotus vil- losus: implications for seabird predators. Comp Biochem Physiol A 78:15-20

Oftedal OT, Bonness DJ, Tedman RA (1987) The behavior, physiology, and anatomy of lactation in the Pinnipedia. In: Genoways HH (ed) Current mammalogy, Vol 1. Plenum Press, New York, p 175-245

Orians GH, Pearson NE (1977) On the theory of central place foraging. In: Horn DJ, Stairs GR, Mitchell RD (eds) Analysis of ecological systems. Ohio State University Press, Columbus, p 153-177

Paul AJ, Paul JM, Brown ED (1998) Fall and spring somatic energy content for Alaskan Pacific herring (Clupea pallasi) relative to age, size, and sex. J Exp Mar Biol Ecol 223: 133-142

Payne PM, Nicolas JR, O'Brien L, Powers KD (1986) The distribution of the humpback whale, Megaptera novaeangliae, on Georges Bank and in the Gulf of Maine in relation to densities of the sand eel, Ammodytes americanus. Fish Bull US Natl Mar Fish Serv 84:271-277

Perez MA (1994) Calorimetry measurements of energy value of some Alaskan fishes and squids. NOAA Techn Rep NMFS AFSC-32

Pitcher KW (1981) Prey of the Steller sea lion, Eumetopias jubatus, in the Gulf of Alaska. US Nat Mar Fish Bull 79: 467-472

Pitcher KW, Calkins DG (1981) Reproductive biology of Steller sea lions in the Gulf of Alaska. J Mammal 62: 599-605

Pitcher KW, Calkins DG, Pendleton GW (1998) Reproductive performance of female Steller sea lions: an energeticsbased reproductive approach. Can J Zool 76:2075-2083

Pritchett D, Hebert K (2003) Southeast Alaska/Yakutat Annual Herring Research Report, 2000/2002 Season. Regional Information Report 1J03-26. Alaska Department of Fish and Game, Division of Commercial Fisheries, Juneau, Alaska

Raum-Suryan, KL Rehburg, MJ, Pendleton, KW, and Gelatt, TS (2004) Development of dispersal, movement patterns, and haulout use by pup and juvenile Steller sea lions Eumetopias jubatus in Alaska. Mar Mammal Sci 20: 823-850

Robbins CT (1983) Wildlife feeding and nutrition. Academic Press, New York

Rodway MS, Regehr HM, Ashley J, Clarkson PV, Goudie RI, Hay DE, Smith CM, Wright KG (2003) Aggregative response of harlequin ducks to herring spawning in the Strait of Georgia, British Columbia. Can J Zool 81:504-514

Rounsefell GA (1930) Contribution to the biology of the Pacific herring, Clupea pallasii, and the condition of the fishery in Alaska. Bull US Bur Fish Vol XLV:227-320

Rounsefell GA, Dalgreen EH (1935) Races of herring, Clupea pallasii, in southeastern Alaska. Bull US Bur Fish Vol XLVIII:119-141

Sease JL, York AE (2003) Seasonal distribution of Steller's sea lions at rookeries and haul-out sites in Alaska. Mar Mammal Sci 19:745-763

Siegel S, Castellan NJ (1988) Nonparametric statistics for the behavioral sciences. 2nd edition. McGraw-Hill Book, New York

Sigler MF, Womble JN, Vollenweider JJ (2004) Availability to Steller sea lions Eumetopias jubatus of a seasonal prey resource: a pre-spawning aggregation of eulachon Thaleichthys pacificus. Can J of Fish Aquat Sci 61:1475-1484

Sinclair EH, Zeppelin TK (2002) Seasonal and spatial differences in diet in the western stock of Steller sea lions (Eumetopias jubatus). J Mammal 84:973-990

Skov HJ, Durinck J, Andell P (2000) Associations between wintering avian predators and schooling fish in the Skag- 
gerrak-Kattegat suggest reliance on predictable aggregations of herring Clupea harengus. J Avian Biol 31: 135-143

Smith ID (1972) Sea lions wintering along the outer coast of Vancouver Island. J Fish Res Board Can 29:18764-1766

Springer AM (1992) A review: walleye pollock in the North Pacific. How much difference do they really make? Fish Oceanogr 1:80-96

Sullivan PJ (1991) Stock abundance estimation using depthdependent trends and spatially correlated variation. Can J Fish Aquat Sci 48: 1691-1703

Sullivan RM (1980) Seasonal occurrence and haul-out use in pinnipeds along Humboldt County, California. J Mammal 61:754-760

Swartzman G, Hunt GL (2000) Spatial association between murres Uria spp., puffins (Fratercula spp.) and fish shoals near Pribilof Islands, Alaska. Mar Ecol Prog Ser 206: 297-309

Thomas GL, Thorne RE (2001) Night-time predation by Steller sea lions: new insight into the feeding habits of these mammals will help conservation attempts. Nature 411:1013

Tolitt DJ, Wong M, Winship AJ, Rosen DAS, Trites AW (2003)

Editorial responsibility: Otto Kinne (Editor-in-Chief), Oldendorf/Luhe, Germany
Quantifying errors associated with using prey skeletal structures from fecal samples to determine the diet of Steller's sea lion Eumetopias jubatus. Mar Mammal Sci 19: $724-744$

Willson MF, Halupka KC (1995) Anadromous fish as keystone species in vertebrate communities. Conserv Biol 9: 489-497

Willson MF, Gende SM, Marston BH (1998) Fishes and the forest: expanding perspectives on fish/wildlife interactions. BioScience 48:455-462

Winship AJ, Trites AW (2003) Prey consumption of Steller sea lions Eumetopias jubatus off Alaska: how much prey do they require? Fish Bull US Natl Mar Fish Serv 101:147-167

Winship AJ, Trites AW, Rosen DAS (2002) A bioenergetic model for estimating the food requirements of Steller sea lions Eumetopias jubatus in Alaska. Mar Ecol Prog Ser 229:291-312

Withrow DE (1982) Using aerial surveys, ground truth methodology, and haul out behavior to census Steller sea lions, Eumetopias jubatus. MS thesis, University of Washington, Seattle, WA

Zar JH (1999) Biostatistical analysis. 4th edn. Prentice-Hall, Upper Saddle River, NJ

Submitted: January 14, 2004; Accepted: December 21, 2004 Proofs received from author(s): May 9, 2005 